\title{
Modulation of the activation of Stat1 by the interferon-gamma receptor complex
}

\author{
Christopher D Krause ${ }^{1}$, Wen $\mathrm{He}^{1}$, Sergei Kotenko², Sidney Pestka ${ }^{1,3,4}$ \\ ${ }^{I}$ Department of Molecular Genetics, Microbiology and Immunology, Robert Wood Johnson Medical School - The University of \\ Medicine and Dentistry of New Jersey, 675 Hoes Lane West, Piscataway, NJ 08855, USA; ${ }^{2}$ Department of Biochemistry \& Molecular \\ Biology, New Jersey Medical School - The University of Medicine and Dentistry of New Jersey, 185 South Orange Avenue, Newark, \\ NJ 07101, USA; ${ }^{3}$ Cancer Institute of New Jersey, 195 Little Albany Street, New Brunswick, New Jersey 08903-2681, USA; ${ }^{4}$ PBL \\ Biomedical Laboratories, 131 Ethel Road West, Suite 6, Piscataway, NJ 08854-5900, USA
}

The activation of Stat1 by the interferon-gamma (IFN- $\gamma$ ) receptor complex is responsible for the transcription of a significant portion of IFN- $\gamma$ induced genes. Many of these genes are responsible for the induction of an apoptotic state in response to IFN- $\gamma$. In the absence of Stat1 activation, IFN- $\gamma$ instead induces a proliferative response. Modifying Stat1 activation by IFN- $\gamma$ may have pharmacological benefits. We report that the rate of activation of Stat 1 can be altered in HeLa cells by overexpressing either the IFN- $\gamma \mathrm{R} 1$ chain or the IFN- $\gamma \mathrm{R} 2$ chain. These alterations occur in hematopoietic cell lines: Raji cells and monocytic cell lines, which have average and above-average IFN- $\gamma \mathrm{R} 2$ surface expression, activate Stat 1 similarly to HeLa cells and HeLa cells overexpressing IFN $\gamma$ R2, respectively. The rapid Stat1 activation seen in HeLa cells can be inhibited by overexpressing a chimeric IFN- $\gamma$ R2 chain that does not bind Jak2 or (when high concentrations of IFN- $\gamma$ are used) by overexpressing IFN- $\gamma \mathrm{R} 1$. These data are consistent with a model in which the recruitment of additional Jak2 activity to a signaling complex accelerates the rate of Stat 1 activation. We conclude that the rate of activation of Stat1 in cells by IFN- $\gamma$ can be modified by regulating either receptor chain and speculate that pharmacological agents which modify receptor chain expression may alter IFN- $\gamma$ receptor signal transduction.

Cell Research (2006) 16:113-123. doi:10.1038/sj.cr.7310015; published online 16 January 2006

Keywords: interferon-gamma, Stat1, interferon-gamma receptor, kinetics, electrophoretic mobility shift assay

\section{Introduction}

Interferon-gamma (IFN- $\gamma$ ) is a cytokine secreted predominantly by Type $1 \mathrm{~T}$ cells (i.e., $\mathrm{T}_{\mathrm{H}} 1$ cells), NK cells, and NKT cells when the immune system is activated by the presence of a viral infection, intracellular bacterial infection, transplanted tissue, and, in autoimmunopathological conditions, by the presence of host tissues. Even in the absence of an infection, the presence of high (local or systemic) concentrations of IFN- $\gamma$ often results in deleterious effects. Inspired by the hypothesis that the presence of IFN- $\gamma$ mediates these pathologies, there has been much interest in understanding how IFN- $\gamma$ signals and, ultimately, in inhibiting its signaling or its deleterious effects.

Correspondence: Sidney Pestka

Tel: 1-732-235-4567; Fax: 1-732-235-5223;

E-mail: pestka@umdnj.edu
IFN- $\gamma$ signals through a preassembled multi-chain transmembrane receptor complex composed of two IFN- $\gamma \mathrm{R} 1$ chains (which bind ligand and recruit Stat transcription factors) and two IFN- $\gamma$ R2 chains (which help to initiate the signal transduction cascades) [1-3]. The interaction of IFN- $\gamma$ with this integral membrane receptor complex results in structural rearrangements in the receptor complex and the activation of Jak1 and Jak2 tyrosine kinases bound to the intracellular domains of IFN- $\gamma \mathrm{R} 1$ and IFN- $\gamma \mathrm{R} 2$ respectively [4-6]. Activation of Jak kinases results in the tyrosine phosphorylation of Jak1 and Jak2 on their kinase domains, and of the COOH-terminus of IFN- $\gamma \mathrm{R} 1$ in two locations, which allow the recruitment of latent Stat 1 and SOCS-1 $[4,7-8]$. Translocation of Stat 1 to the nucleus allows Stat1 to modify the transcription of a fraction of IFN- $\gamma$-sensitive genes $[9,10]$. IFN- $\gamma$ signaling is silenced primarily by the recruitment of SOCS proteins to the IFN- $\gamma$ receptor complex [11]. Inhibition of IFN- $\gamma$ signal transduction by 
phosphatases [12-14] and PIAS proteins [15] has also been demonstrated [16].

Though the activation of Stat 1 only accounts for a fraction of all IFN- $\gamma$-induced genes, the genes induced by Stat 1 play a predominant role in most of the major biological activities of IFN- $\gamma$. Among these genes is SOCS-1 [11, 17, 18]. SOCS- 1 binds to IFN- $\gamma$ R 1 and the activation loop of Jak2 (and possibly also Jak1) and prevents either the recruitment of additional Stat proteins or the phosphorylation of target proteins by the Jak kinases [8, 19]; thus SOCS-1 can repress signaling by not only IFN- $\gamma$ but by other cytokines using the Jak/Stat pathway. Another notable gene induced by Stat1 is IRF-1, whose induction is necessary for the upregulation of MHC Class I and Class II [20, 21], FasL [22], and caspases- 1 and -8 [23, 24] by IFN- $\gamma$. Also induced by Stat1 are several genes involved in promoting apoptotic effects, such as several receptors or ligands of the TNF family [25-35], caspases [31, 36-38], and enzymes that destroy tryptophan [39].

Due to the induction of pro-apoptotic genes, IFN- $\gamma$ induces apoptosis in a wide variety of cells, either by itself, or assisted by at least one member of the TNF superfamily [40-42]. However, in some cases, it has been demonstrated that IFN- $\gamma$ can induce proliferative responses [43-50]. A mechanism for this alternative pathway for IFN- $\gamma$ had been elusive until it was shown that in the absence of Stat1, IFN- $\gamma$ induces proliferative responses [9], and that IFN- $\gamma$ could induce proliferative responses when Stat1 was present as long as it was not activated. Conversely, interleukin-6, which normally has beneficial effects on tissues can activate Stat 1 and induce apoptotic effects when Stat 3 is missing from cells [51]. Therefore, it appears that the activation of Stat1 was responsible for inducing the apoptotic effects of cytokines.

Previous research demonstrated that the IFN- $\gamma$ receptors present in monocyte cell lines vary from those present in non-hematopoietic cell lines $[52,53]$, implying that the IFN- $\gamma$ receptor is subject to significant modification. One group has shown that modification of $\mathrm{T}$ cell lines so that their IFN- $\gamma$ receptors were upregulated on the cell surface resulted in a change in their response to IFN- $\gamma$ from proliferation to apoptosis $[45,46,54]$. This change to an apoptotic response correlated with a robust activation of Stat1 in response to IFN- $\gamma$ [50]. In other cases, repression of IFN- $\gamma$ R2 expression was seen in T cell subsets, but this repression usually was strong enough to render $\mathrm{T}$ cells unresponsive to IFN- $\gamma$ [55-59]. Notably, cells that secrete IFN- $\gamma$ often have low levels of the IFN- $\gamma$ receptor chains, probably to resist the negative effects of the IFN- $\gamma$ that they synthesize and secrete. Nevertheless, a correlation between Stat 1 activation and IFN- $\gamma$ receptor expression is evident.
The work in this study was undertaken to investigate the link between IFN- $\gamma$ receptor chain expression and the cellular activation of Stat1. Modification of IFN- $\gamma$-induced Stat1 signaling by changing the receptor instead of changing Stat1 is an additional avenue by which IFN- $\gamma$ signaling can be pharmacologically manipulated. Additionally, modification of IFN- $\gamma$ receptors may affect aspects of IFN- $\gamma$ signaling than Stat 1 activation, yielding other opportunities for pharmacological relief of IFN- $\gamma$-mediated immunopathologies. We found that overexpression of IFN- $\gamma$ receptor chains altered the activation of Stat 1 by IFN- $\gamma$. These alterations can be seen in hematopoietic cell lines implying that these alterations likely occur under physiological situations. We discovered that the activation of Statl seen in most cell lines is slower when receptor chains that do not bind a Jak kinase are overexpressed. From these data, we constructed a model explaining how interactions between receptor chains after their activation by IFN- $\gamma$ change the rate of Stat1 activation.

\section{Materials and methods}

\section{Reagents and chemicals}

Wild type IFN- $\gamma$ was purified as published previously [60]. Plasmids pEF2-FL-IFN- $\gamma$ R2 $/ \gamma R 2$, pEF2-FL-IFN- $\gamma$ R $/ \alpha R 2 b$ and pEF2-FL-IFN- $\gamma$ R2/IL-10R2 were described previously [61]. These plasmids encode chimeric receptor proteins in which the transmembrane and intracellular domains of IFN- $\gamma \mathrm{R} 2$ were unaltered, or were exchanged for those of IFN- $\alpha$ R2b and IL-10R2, and bind either Jak2, no Jak kinase, or Tyk2 respectively. The FLAG epitope was inserted into the $\mathrm{NH}_{2}$-terminus of IFN- $\gamma \mathrm{R} 2$ and IL-10R2 after the signal peptide, and does not interfere significantly with receptor functionality $[61,62]$. The plasmid encoding pEF2-IFN- $\gamma \mathrm{R} 1$ was described previously [63].

\section{Tissue Culture}

Cell lines were grown in stationary flasks in standard tissue culture incubators $\left(37^{\circ} \mathrm{C}, 5 \% \mathrm{CO}_{2}, 99 \%\right.$ relative humidity) without antibiotics. HEp-2 cells were grown in MEM medium supplemented with $10 \%$ (v:v) fetal bovine serum (FBS). HeLa and COS-1 cells were grown in DMEM medium supplemented with $10 \%$ FBS. HL-60, Raji, and U937 cells were grown in RPMI medium supplemented with $10 \%$ FBS.

\section{Transfections}

HeLa cells were transfected with plasmids by the electroporation method. Briefly, $3 \times 10^{7}-6 \times 10^{7} \mathrm{HeLa}$ cells grown as above to $90 \%$ confluence were harvested with trypsin, washed twice with ice cold phosphate-buffered saline (PBS), then finally resuspended in $0.45 \mathrm{~mL}$ PBS at ambient temperature. The DNA $(10 \mu \mathrm{g}$ in $10 \mu \mathrm{L})$, and cells were mixed together by gentle pipetting, and were transferred to a electroporation cuvette with a $4 \mathrm{~mm}$ gap. Cuvettes were pulsed with a Bio-Rad GenePulser II electroporator at $220 \mathrm{~V}, 950 \mu \mathrm{F}$ current for $18 \mathrm{~ms}-30 \mathrm{~ms}$. After electroporation, the cells were resuspended in 12 mL DMEM with 10\% FBS and distributed into 96-well plates at a density that yielded an average of 0.2 colonies per well. Three days 
post-electroporation, selection of transfected colonies was begun by addition of $450 \mu \mathrm{g} / \mathrm{mL}$ geneticin. Colonies containing cells which survived selection were grown without antibiotic and were screened for the expression of receptor by flow cytometry with murine monoclonal anti-FLAG antibodies (Sigma) or murine monoclonal $\gamma$ R99 antibodies to detect the human IFN- $\gamma$ R1 extracellular domain [64]. All experiments were performed with these clonal cell lines.

\section{Electrophoretic Mobility Shift Assays (EMSA)}

The EMSA was performed essentially as described previously $[65,66]$ with changes only in how the cells were lysed.

For adherent cells, IFN- $\gamma$ was diluted in DMEM media/10\% FBS at $37^{\circ} \mathrm{C}$ to a concentration of 1000 units $/ \mathrm{mL}$ (2940 pM) unless otherwise stated. Cells were grown to and maintained at confluence for at least two days in 12-well Falcon tissue culture dishes (1.3 $\times 10^{7}$ cells/well $)$ or 24 -well Falcon tissue culture dishes $\left(3.7 \times 10^{6}\right.$ cells/well) prior to ligand treatment. Cells were incubated in $1 \mathrm{~mL}$ of ligand-containing medium for various times at $30^{\circ} \mathrm{C}-37^{\circ} \mathrm{C}$ as noted. Twenty seconds prior to stopping the reaction, medium was removed, and cells were washed with $2 \mathrm{~mL}$ ambient PBS. PBS was removed immediately before the cells were scraped in 50 or 100 $\mu 1$ of Lysis Buffer (0.5\% Brij-96, 10\% glycerol, $0.1 \mathrm{mM}$ EDTA, $50 \mathrm{mM}$ Tris- $\mathrm{HCl}(\mathrm{pH} 8.0), 3 \mu \mathrm{g} / \mathrm{ml}$ aprotinin, $1 \mu \mathrm{g} / \mathrm{ml}$ leupeptin, $1 \mu \mathrm{g} / \mathrm{ml}$ pepstatin, $1 \mathrm{mM} \mathrm{Na} \mathrm{VO}_{4}, 1 \mathrm{mM}$ dithiothreitol, $0.2 \mathrm{mM}$ phenylmethylsulfonylfluoride (PMSF), and $150 \mathrm{mM} \mathrm{NaCl}$ ). Lysates were stored at $-80^{\circ} \mathrm{C}$ until used.

Cells in suspension were grown overnight in fresh medium. Immediately before the experiment the cells were pelleted then resuspended in $1.2 \mathrm{~mL}$ of appropriate media to a concentration of $1 \times 10^{8}$ cells $/ \mathrm{mL}$. After at least $1 \mathrm{~h}$ to allow the cellular suspension to come to equilibrium in the incubator, $100 \mu \mathrm{l}$ of this suspension was removed as the control without IFN- $\gamma$ treatment. IFN- $\gamma$ was added to the remaining cellular suspension to a concentration of 1000 units/mL (2940 pM) unless otherwise indicated and incubated at $37^{\circ} \mathrm{C}$. At the appropriate time intervals, $100 \mu \mathrm{l}$ of the cell suspension was removed, immediately diluted into $1.0 \mathrm{~mL}$ of ice cold PBS and maintained at $4^{\circ} \mathrm{C}$ in an ice bath. After all the samples were collected, each cell suspension was centrifuged at $1,100 \times \mathrm{g}, 4^{\circ} \mathrm{C}$, the supernatant removed, the pellet suspended in $25 \mu \mathrm{L}$ of ice cold Lysis Buffer, and stored at $-80^{\circ} \mathrm{C}$ until used. In some reactions, ice cold PBS was substituted for ice cold RSB buffer (10 mM Tris $\mathrm{HCl}$, $\mathrm{pH} 7.4,10 \mathrm{mM} \mathrm{NaCl}, 3.3 \mathrm{mM} \mathrm{MgCl}$ ), and cells were lysed with detergent-free hypertonic lysis buffer (20 mM HEPES, pH 7.9, 20\% glycerol, $420 \mathrm{mM} \mathrm{NaCl}, 1.5 \mathrm{mM} \mathrm{MgCl}_{2}, 0.2 \mathrm{mM}$ EDTA, $0.2 \mathrm{mM}$ PMSF, $1 \mathrm{mM}$ DTT, $0.1 \mathrm{mM} \mathrm{Na} \mathrm{VO}_{4}, 3 \mu \mathrm{g} / \mathrm{mL}$ aprotinin, $1 \mu \mathrm{g} / \mathrm{mL}$ pepstatin, $1 \mu \mathrm{g} / \mathrm{mL}$ leupeptin) [67].

After lysis, aliquots were analyzed by the Electrophoretic Mobility Shift Assay (EMSA) as described previously [66]. Briefly, after a $30 \mathrm{~min}$ incubation on ice, $2.5 \mu \mathrm{L}$ of lysate was added to $10 \mu \mathrm{L}$ of a mixture of $0.2 \mathrm{mg} / \mathrm{mL}$ poly(dI) $\cdot \operatorname{poly}(\mathrm{dC}), 1 \%$ Ficoll, $4 \mathrm{mM}$ HEPES, pH 7.4, $30 \mu \mathrm{g} / \mathrm{ml} \mathrm{BSA}$, and approximately $0.2 \mathrm{ng}$ of a double-stranded oligonucleotide encoding the GAS element from the human $\boldsymbol{I R F - 1}$ gene promoter (5'-GATCGATTTCCCCGAAATCATG-3'). The consensus binding site for the Stat 1 dimer is in boldface. After incubation for $20 \mathrm{~min}$ at ambient temperature, samples were loaded onto a 5\% native polyacrylamide gel and resolved at $4^{\circ} \mathrm{C}$ for $4 \mathrm{~h}$ at $450 \mathrm{~V}$. Immediately afterward, the gel was dried under vacuum at $80^{\circ} \mathrm{C}$ for $60 \mathrm{~min}$, and subjected to autoradiography or was analyzed quantitatively on a GS-525 Molecular Analyzer phos- phorimager with the supplied Molecular Analyst software (BioRad, Hercules CA). Phosphorimaging screens were erased immediately before use to increase the sensitivity of detection by lowering the nonspecific background phosphorescence [68]. SigmaPlot software (Systat) was used to analyze the quantified intensities. The value at the zero-time point (no addition of IFN- $\gamma$ ) was subtracted from each normalized value so that there is zero signal initially in all graphs.

\section{Results}

Modulation of Stat1 activation in HeLa cells by overexpression of IFN- $\gamma$ receptor chains

The activation of Stat 1 in HeLa cells upon treatment with 1000 units/mL (2940 pM) IFN- $\gamma$ as a function of time using the Electrophoretic Mobility Shift Assay (EMSA) is shown in Figure 1A. All the available Stat1 in the cell bound to DNA in about ten minutes (Figure 1A, B). Quantitation of the EMSA demonstrated that after a brief latency period lasting for about a minute, Stat 1 is very quickly activated (Figure 1B). A similar pattern of Stat1 activation was observed in other epithelial cell lines (HEp-2, COS-1). After one hour, the amount of Stat 1 seen in the EMSA decreased (data not shown).

To ensure that transfection of receptors would not change the activation of Stat 1 in response to IFN- $\gamma$ nonspecifically, the kinetics of Stat 1 activation in HeLa cells overexpressing the irrelevant receptor chain IL-10R2 was determined; the kinetics of Stat 1 activation were unchanged (data not shown).

The activation of Stat1 in HeLa cells overexpressing IFN- $\gamma$ R2 showed that Stat1 was activated quickly in response to $2940 \mathrm{pM}$ IFN- $\gamma$, similar to untransfected HeLa cells; however, the initial activation of Stat1 was faster (Figure 1C). Quantitation of this EMSA confirmed this result (Figure 1D, filled circles), demonstrating the loss of the latent phase (Figure 1D, inset). Overexpression of the chimeric receptor chain FL-IFN- $\gamma$ R2/IL-10R2 that binds Tyk2 instead of Jak2 yielded kinetics similar to that caused by overexpression of the FL-IFN- $\gamma$ R2/ $\gamma$ R2 chain (Figure 1D, open circles), confirming that the Jak kinases are interchangeable with respect to the activation of Stat proteins as reported previously [61]. The decrease of the latent phase caused by overexpression of IFN $-\gamma \mathrm{R} 2$ is more apparent at lower concentrations of IFN- $\gamma$; however, a latent phase shows up in all kinetic experiments because the complete binding of IFN- $\gamma$ to receptor occurs only after several minutes so that under these conditions receptors are progressively activated (data not shown).

The activation of Stat1 in HeLa cells overexpressing IFN- $\gamma$ R1 was unusual. In untransfected HeLa cells (Figure 2A, top, Figure 2B, open circles) and in HeLa cells overexpressing IFN- $\gamma$ R2 (data not shown), the activation of Stat 1 at $15 \mathrm{~min}$ in response to increasing concentrations 
A

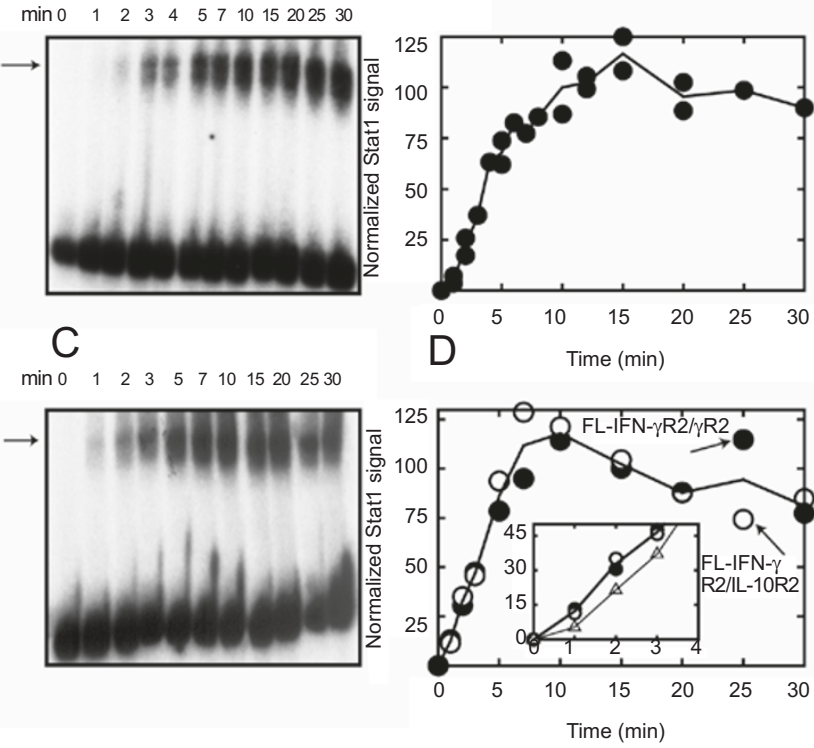

Figure 1 Time-dependant Statl activation in HeLa cells and HeLa cells overexpressing IFN- $\gamma$ R2. HeLa cells $(\mathbf{A}, \mathbf{B})$ and HeLa cells overexpressing IFN- $\gamma$ R2 (C, D) were grown as described in the Materials and Methods section, and were treated for the indicated times with 2940 pM (1000 units/mL) IFN- $\gamma$. Whole-cell lysates were incubated with radiolabeled GAS probe and resolved by native PAGE, and the radioactive gel was digitized by phosphorimagery. (A) The image of the EMSA assay. Bands corresponding to the GAS probe bound to Stat1 (upper bands) and to the internal nonspecific protein (lower bands) are displayed. The arrow points to the complex of the GAS probe with Stat1. The numbers above each well indicate the time of treatment with IFN- $\gamma$ prior to lysis. (B) The intensities of the Stat 1 band and the nonspecific band were quantitated, and normalized values of Stat1 activity are plotted as a function of time. The results of two different quantitated gels are shown as filled circles and the average of duplicates at various time points are shown with the solid line. (C) Image of the EMSA. Bands corresponding to GAS probe bound to Stat 1 and to the internal nonspecific protein are displayed. The arrow points to the complex of the GAS probe with Stat1. The numbers above each well indicate the time of treatment with IFN- $\gamma$ prior to lysis. (D) The intensities of the Statl band and the nonspecific band were quantitated, and normalized values of Stat 1 activity are plotted as a function of time. Filled circles, results from HeLa cells overexpressing FL-IFN- $\gamma$ R2 $/ \gamma$ R2. Open circles, results from HeLa cells overexpressing FL-IFN- $\gamma$ R2/IL-10R2. The line shows the average value of the normalized Stat 1 activation from the two cell lines (average of filled and open circles). The averaged HeLa cell data from Figure 1B is replotted with a thinner line and open triangles. The points nearly completely overlap at $20 \mathrm{~min}$; this overlap is shown with a half-filled circle. The inset shows an expansion of the first 4 min of Stat l activation to visualize the latent phase more easily.

of IFN- $\gamma$ was dose-dependant and was optimal above 34 units/mL (100 pM). However, in HeLa cells overexpressing IFN- $\gamma \mathrm{R} 1$, the dose-response relationship was biphasic: below $100 \mathrm{pM} \mathrm{IFN- \gamma}$ the relationship was identical to that of untransfected HeLa cells while above 100 pM, increasing IFN- $\gamma$ concentrations resulted in diminishing Stat 1 activation (Figure 2A, bottom, Figure 2B, filled circles). To confirm this result, kinetics of Stat 1 activation were measured in HeLa cells and HeLa cells overexpressing IFN- $\gamma \mathrm{R} 1$ at $35 \mathrm{pM}$ IFN- $\gamma$; the observed kinetics were similar (data not shown). On the other hand, when the kinetics were followed in HeLa cells overexpressing IFN- $\gamma \mathrm{R} 1$ in response to 2940 $\mathrm{pM}$ IFN- $\gamma$, the rapid Stat 1 activation seen in untransfected HeLa cells or in HeLa cells overexpressing IFN- $\gamma$ R2 did not occur (Figure 2C, 2D): almost an hour was needed before complete Stat1 activation was observed (Figure 2C). The decreasing phase of the biphasic dose-response is therefore
A

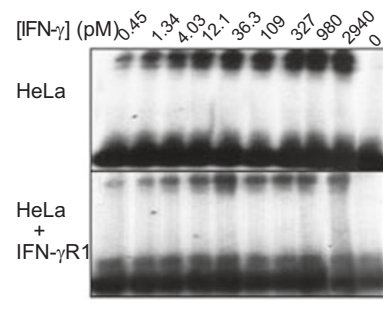

C

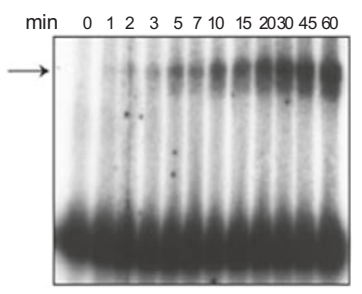

B

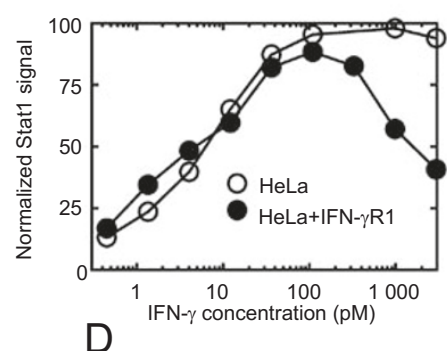

D

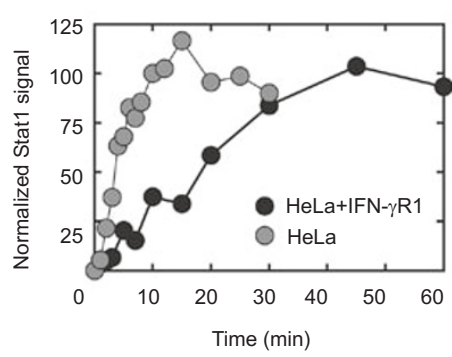

Figure 2 Stat 1 activation in HeLa cells overexpressing IFN- $\gamma$ R1. (A) Dose response curves of Stat 1 activation as a function of IFN- $\gamma$ concentration. The indicated concentrations of IFN- $\gamma$ were added to untransfected HeLa cells (top panel) and HeLa cells overexpressing IFN- $\gamma$ R1 (bottom) for 15 min and the EMSA was run. The gels were compressed vertically to fit into a single panel. (B) The dose-response of untransfected HeLa cells (open circles) and of HeLa cells overexpressing IFN- $\gamma \mathrm{R} 1$ (filled circles) from Figure 2A were quantitated. (C) Slow Stat1 activation in HeLa cell overexpressing IFN- $\gamma$ R1. HeLa cells overexpressing IFN- $\gamma$ R1 were treated with 2940 pM IFN- $\gamma$ for the indicated times, and lysates were resolved by EMSA. The image of the resulting digitized gel is shown. The arrow points to the complex of the GAS probe with Stat1. The numbers above each well indicate the time of treatment with IFN- $\gamma$ prior to lysis. (D) Quantitation of the kinetics displayed in Figure 2C. Results with HeLa cells overexpressing IFN- $\gamma$ R1 are shown with filled circles. The data from Figure 1B (untransfected HeLa cells) are repeated as grey circles for comparative purposes. 
A
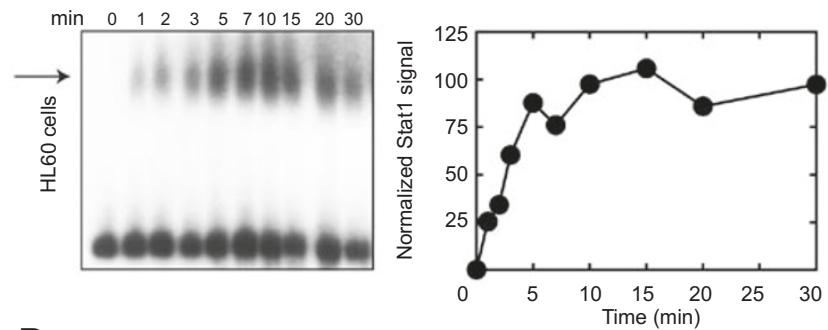

B
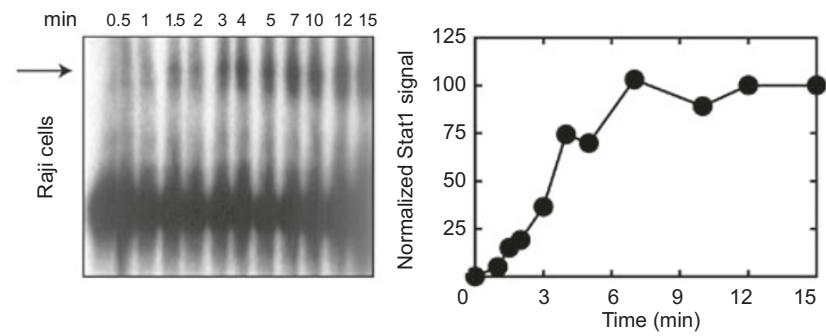

Figure 3 (A) Stat1 activation kinetics in HL60 cells. HL60 cells were grown and treated with $2940 \mathrm{pM}$ IFN- $\gamma$ as in the Materials and Methods section, for the indicated times. (left) image of the resulting EMSA. The arrow points to the complex of the GAS probe with Stat1. The numbers above each well indicate the time of treatment with IFN- $\gamma$ prior to lysis. (right) results of the quantitated EMSA. (B) Stat1 activation kinetics in Raji cells. Raji cells were grown and treated with $2940 \mathrm{pM}$ IFN- $\gamma$ as in the Materials and Methods section, for the indicated times. (left) image of the resulting EMSA. The arrow points to the complex of the GAS probe with Stat1. The numbers above each well indicate the time of treatment with IFN- $\gamma$ prior to lysis. (right) results of the quantitated EMSA.

due to the inhibition of Stat 1 activation by the excess levels of IFN- $\gamma \mathrm{R} 1$ in these cells.

Stat1 activation in untransfected hematopoietic cell lines varies

These results prompted us to look at the kinetics of Stat 1 activation in cell lines that are known to differentially regulate the surface expression level of their IFN- $\gamma$ receptor chains. Myeloid cell lines (HL60, THP-1, U937) generally have high IFN- $\gamma \mathrm{R} 2$ levels on their cell surface while B cell lines (Raji) have lower IFN- $\gamma$ R2 levels on the cell surface [50]. The kinetics of Statl activation in response to 2940 pM IFN- $\gamma$ in HL60 cells and Raji cells were assessed. We found that the kinetics of Stat 1 activation in HL60 cells (as well as in U937 and THP-1 cells; data not shown) resembled that of HeLa cells overexpressing IFN- $\gamma$ R2 (Figure $3 \mathrm{~A}, \mathrm{~B}$ ) in that no latency period existed, while in Raji cells, the kinetics of Stat 1 activation revealed the presence of a latency period reminiscent of that found in untransfected HeLa cells (Figure 3C, D). There is therefore a good cor- relation between the kinetic response of Stat1 activation and the relative levels of IFN- $\gamma$ R2 in each set of cell lines. We conclude that the alterations in Stat 1 activation occurring in various hematopoietic cell lines that we observed here are likely modulated by the differential levels of the IFN- $\gamma \mathrm{R} 1$ and IFN- $\gamma R 2$ chains. The results of Stat 1 activation in $T$ cells were published previously [50].

Inhibition of rapid Stat 1 activation by a dominant-negative chimeric IFN- $\gamma R 2$ chain

The inhibition of rapid Statl activation in the presence of high levels of the IFN- $\gamma \mathrm{R} 1$ chain, and the loss of the lag in activation of Stat1 when IFN- $\gamma$ R2 was overexpressed led us to speculate that an element of the IFN- $\gamma \mathrm{R} 2$ chain is responsible for the onset of the rapid Stat1 activation rate. To delineate this element, we took advantage of chimeric receptors, in which the transmembrane and intracellular domains can be altered without altering the ability of the resulting receptor chain to initiate IFN- $\gamma$ signaling [61]. Changing the intracellular domain to that of a functional receptor IL-10R2 that recruits Tyk2 did not alter the kinetics (Figure 1D, right). Thus we overexpressed the chimeric receptor chain FL-IFN- $\gamma \mathrm{R} 2 / \alpha \mathrm{R} 2 \mathrm{~b}$ that does not activate the IFN- $\gamma$ receptor complex because its intracellular domain does not bind a Jak kinase [61]. Though soluble IFN- $\gamma$ R2 inhibited IFN- $\gamma$ signal transduction [1], we instead found that the kinetics of Stat1 activation in response to $2940 \mathrm{pM}$
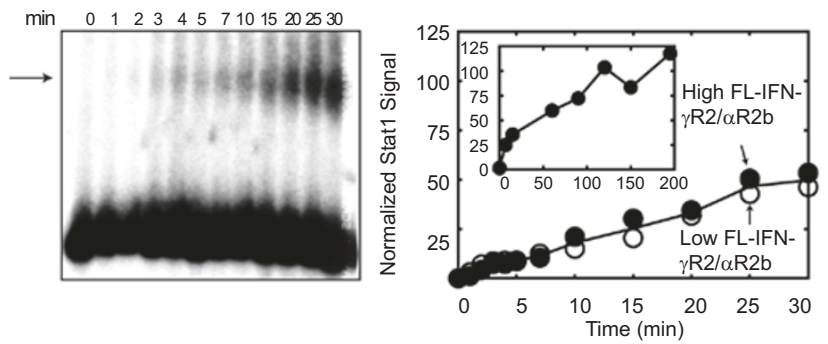

Figure 4 Statl activation kinetics in HeLa cells overexpressing FL-IFN- $\gamma$ R2/ $\alpha$ R2b. Cells were treated with 2940 pM IFN- $\gamma$. (left) Image of the EMSA. Bands corresponding to GAS probe bound to Stat 1 and to the internal nonspecific protein are displayed. The arrow points to the complex of the GAS probe with Stat1. The numbers above each well indicate the time of treatment with IFN- $\gamma$ prior to lysis. (right) The intensities of the Stat1 band and the nonspecific band were quantitated, and normalized values of Stat1 activity are plotted as a function of time. Open circles represent the activation of Stat 1 in the clone expressing tenfold lower FL-IFN- $\gamma$ R2/ $\alpha$ R2b levels, while the filled circles represent the activation of Stat 1 in the clone expressing high FL-IFN- $\gamma$ R $2 / \alpha$ R $2 b$ levels. The inset shows a separate experiment in which the kinetics in the HeLa cell clone expressing high levels of FL-IFN- $\gamma$ R $2 / \alpha$ R $2 b$ were followed for a longer period of time. 
IFN- $\gamma$ in HeLa cells overexpressing FL-IFN- $\gamma$ R $2 / \alpha$ R $2 b$ at a high level (Figure 4, filled circles) were similar to those of HeLa cells overexpressing IFN- $\gamma$ R1 (Figure 2D). Similar results were obtained in a different cell clone expressing approximately tenfold less FL-IFN- $\gamma$ R2/ $\alpha$ R2b (Figure 4, open circles), suggesting that the amount of FL-IFN- $\gamma \mathrm{R} 2 /$ $\alpha \mathrm{R} 2 b$ is sufficient for maximal effect in both clones; the results with both clones FL-IFN- $\gamma$ R2/ $\alpha$ R $2 b$ are displayed. Over two hours were required for complete Stat1 activation to be seen (Figure 4 right, inset). We conclude that the dominant-negative receptor chain also prevents rapid Stat1 activation.

\section{Discussion}

The activation of Stat 1 by the IFN- $\gamma$ receptor complex is a well-understood signaling pathway. Moreover, the effects of Stat 1 activation by IFN- $\gamma$ on cellular physiology are known. Several groups have shown, summarized below, that the actions of Stat 1 can be regulated; however, this regulation involves either gene induction of protein inhibitors or post-translational modification of Stat1, which may affect the activation of Stat 1 by other cytokines. We offer in this report a novel mechanism of Stat1 regulation that confines the regulation to the IFN- $\gamma$ signaling pathway by involving only the IFN- $\gamma$ receptor chains.

The fact that Stat1's presence or absence can modify how IFN- $\gamma$ signals implies that there may be mechanisms in the cell to regulate the activation or expression of Stat1 $[69,70]$. Repression of Stat 1 mRNA by inducible factors has not been reported, though the ubiquitously expressed protein ZBP-89 must be present for the Stat1 gene to be expressed or induced by IFN- $\gamma$ [71]. Cells generally express Stat1 constitutively; regulation of protein levels of Stat 1 has only been shown in the context of paramyxoviral infection, where Stat1 is proteolytically processed to yield a dominant-negative form $[72,73]$. SOCS protein family members have been shown to inhibit the activation of Stat proteins either by binding to the cytokine receptor complex and preventing Stat recruitment, or by binding Jak kinases and inhibiting their activities. The latter likely inhibits receptor signaling too globally to specifically affect Stat 1 activation. Pias 1 interacts with activated Stat 1 molecules and prevents translocation of Stat 1 to the nucleus [15]. This may occur at least in part by its ability to SUMOlate Stat 1 by conjugating the protein SUMO-1 to Stat1 Lys-703 $[74,75]$, which may disrupt the interaction between the phosphorylated Tyr-701 and Stat SH2 domains. However, inactivation of the of Pias1 gene in mice only affected Stat1-modulated IFN-induced genes involved in innate immunity [76], demonstrating that many Stat1-regulated IFN-induced genes are not inhibited by Pias1. This may be explained by several conditions: (1) SUMO-1 is present only at low levels, (2) only low levels of SUMOlated Stat 1 are observed endogenously after activation of Stat 1 by IFN- $\gamma$, and (3) significant effects of SUMO-1 and Pias1 on Stat1 activity in cell lines has been demonstrated only in overexpression experiments. Perhaps increased endogenous expression of SUMO-1 may affect Stat1 activation more globally, or the effects of SUMO-1 and Pias1 become more apparent when IFN- $\gamma$ needs to activate only limited quantities of Stat1. Immature macrophage cell lines differ from mature macrophage cell lines in they are not robustly activated by IFN- $\gamma$ and cannot upregulate their MHC Class I surface antigen in response to IFN- $\gamma$, though they possess a functional IFN- $\gamma$ receptor complex and express normal levels of Stat 1 ; significantly, immature macrophages cannot activate Stat 1 in response to IFN- $\gamma$ [77-80]. Detailed studies of the phosphorylation state of Stat 1 in these cell lines show that Stat 1 is hypo-phosphorylated on serine residues in immature macrophages relative to what is found in mature macrophages [77]. Perhaps the serine phosphorylation state of Statl can regulate its ability to be activated by IFN- $\gamma$. In addition, in murine $\mathrm{C} 243$ cells Stat1 (as a GFP fusion) once activated by IFN- $\gamma$, was translocated into and later exported from the nucleus, and could not be immediately reactivated by IFN- $\gamma[81]$, implying that mechanisms are in place to keep Stat1 from being activated under some circumstances.

That cells can change their cell fate in response to IFN- $\gamma$ has been reported. One report shows that IFN- $\gamma$ induced apoptosis only at higher IFN- $\gamma$ concentrations [82]. Others show that $\mathrm{T}$ cells stimulated through their T-cell antigen receptor (TCR) proliferate in response to IFN- $\gamma$ during the first TCR activation, but undergo apoptosis in response to IFN- $\gamma$ during a second TCR activation $[45,46]$. In another case, serum starvation caused $\mathrm{T}$ cells, which normally proliferate in response to IFN $-\gamma$, to undergo apoptosis in response to IFN- $\gamma[45,46,50,54]$.

Changes in IFN- $\gamma$ receptor chain expression have been noted, and in one system, correlated with changes in cell fate. $T_{H} 1$ and $T_{C} 1$ cells express less IFN- $\gamma$ R2 mRNA than $\mathrm{T}_{\mathrm{H}} 2$ and $\mathrm{T}_{\mathrm{C}} 2$ cells in some circumstances, and express no IFN- $\gamma$ R 2 mRNA in other circumstances [55-59]; however, others have seen IFN- $\gamma \mathrm{R} 2$ expression in $\mathrm{T}_{\mathrm{H}} 1$ cells [46]. Moreover, transcription run-off assays with IFN- $\gamma$ R2 show that transcription initiation can begin from many points within the IFN- $\gamma \mathrm{R} 2$ promoter in vitro [83-84], so that the lack of a single band may not necessarily mean that the mRNA is not expressed. In another system TCR activation caused a transient decrease in the IFN- $\gamma \mathrm{R} 1$ cell surface expression [85]. Several groups have seen upregulation of the IFN- $\gamma$ R2 chain in T cells during their stimulation [45, $46,58,59]$. Hematopoietic cell lines as well as peripheral 
blood mononuclear cells isolated from blood show variations in their IFN- $\gamma \mathrm{R} 2$ cell surface expression [50]; the variability in T cells is due to active shuttling of IFN- $\gamma \mathrm{R} 2$ from early endosomes to the cell surface [86]. Serum starvation enhances IFN- $\gamma \mathrm{R} 1$ expression in T cells [54], and enhances IFN- $\gamma \mathrm{R} 2$ cell surface expression in a variety of hematopoietic cell lines; this latter effect may be due to deprivation of IGF-1 [87].

Notably, enhanced activation of Stat 1 occurred with the upregulation of IFN- $\gamma \mathrm{R} 2$ and an IFN- $\gamma$-induced proapoptotic fate during serum starvation, establishing a three-way correlation, but how these pathways are linked was not certain. Forced expression of IFN- $\gamma \mathrm{R} 2$ in $\mathrm{T}$ cells forces them to undergo apoptosis in response to IFN- $\gamma$ even in the presence of serum [50]; this formally dissolved a direct link between serum deprivation and Stat 1 activation preceding apoptosis and implied that the receptor levels directly control cell fate in response to IFN- $\gamma$. We undertook this study to see if the modulation of the receptor expression level could modify the activation of Stat 1 directly. We found that overexpression of either IFN- $\gamma$ receptor chain modified the time course of Stat 1 activation (Figures 1B, 1D, 2C, 2D), implying that serum deprivation acts predominantly in $T$ cells to enhance the expression on the cell surface of the IFN- $\gamma$ receptor chains. Notably, the variations in Stat 1 activation seen were recapitulated in normal hematopoietic cell lines, such as in myeloid cell lines like HL60 (Figure $3 \mathrm{~A}$ ), and lymphoid cells like the B cell line Raji (Figure 3B), and T cells like Jurkat [50]. This implies that even physiological upregulation of the IFN- $\gamma$ receptor chains is sufficient to modify the Stat1 activation rate in cells.

The expression of the IFN- $\gamma \mathrm{R} 2$ chains with respect to the IFN- $\gamma \mathrm{R} 1$ chain correlated with the overall appearance of activated Stat1 in a short period of time. In normal epithelial cell lines and in B cell lines like Raji cells (that have an intermediate cell surface IFN- $\gamma \mathrm{R} 2$ expression), rapid Stat1 activation in response to high concentrations of IFN- $\gamma$, is seen but only after a short slow phase (Figures 1A, 1B, 3B). In HeLa cells overexpressing IFN- $\gamma \mathrm{R} 2$ and in myeloid cell lines (that have higher IFN- $\gamma \mathrm{R} 2$ surface expression), the slow phase has been eliminated (Figs. 1C, 1D, 3A). In HeLa cells overexpressing IFN- $\gamma \mathrm{R} 1$ and in HeLa cells overexpressing IFN- $\gamma$ R2/ $\alpha$ R2 $b$ (Figures $2 C, 2 D$, 4 ), rapid Stat1 activation is never seen and only the slow Stat 1 activation is seen. This pattern of Stat 1 activation is reminiscent of what was seen in Jurkat cells [50], in which IFN- $\gamma$ R2 levels on the cell surface are low. This data suggests that two rates of Stat1 activation can be initiated by IFN- $\gamma$. Rapid Stat 1 activation allows that Stat1-inducible, pro-apoptotic pathway to be seen, and is the one seen in the majority of cell lines and biological situations. Slower Stat 1 activation allows pathways such as the proliferative pathway to be initiated. One could speculate a "footrace" between a Stat1-inducible pathway and a proliferative pathway for the final cell fate commitment when responding to IFN- $\gamma$. Changing the rate of Stat1 activation would be an effective way to control whether Stat1 will win or lose this footrace.

The inhibition of rapid Stat 1 activation by overexpression of IFN- $\gamma \mathrm{R} 1$ occurred only at high concentrations of IFN- $\gamma$ (Figure 2). Under these conditions, preassembled IFN- $\gamma$ R 1:IFN- $\gamma$ R 2 complexes will coexist with free IFN- $\gamma \mathrm{R} 1$, and both can bind IFN- $\gamma$. It has been shown that binding of IFN- $\gamma$ to cells coexpressing IFN- $\gamma \mathrm{R} 2$ and IFN- $\gamma \mathrm{R} 1$ is of higher affinity than the binding of IFN- $\gamma$ to IFN- $\gamma \mathrm{R} 1$ alone by a factor of three $[1,88]$. Furthermore, a lower-affinity IFN- $\gamma$ binding site could be seen in addition to the regular high-affinity IFN- $\gamma$ binding site under some conditions [89]. Thus at lower IFN- $\gamma$ concentrations, IFN$\gamma$ seems to preferentially bind to preassembled IFN- $\gamma$ R1: IFN- $\gamma$ R 2 complexes. Even when IFN- $\gamma$ binds to IFN- $\gamma$ R 1 alone at lower IFN- $\gamma$ concentrations (which will occur because IFN- $\gamma \mathrm{R} 1$ is overexpressed) an exchange of IFN$\gamma \mathrm{R} 2$ between IFN- $\gamma \mathrm{R} 1$ chains would allow high-affinity complexes to form by the secondary recruitment of IFN$\gamma \mathrm{R} 2$ to the IFN- $\gamma$ :IFN- $\gamma \mathrm{R} 1$ complex. We predict that this takes place because (i) in the absence of ligand, IFN- $\gamma \mathrm{R} 1$ and IFN- $\gamma \mathrm{R} 2$ cannot coimmunoprecipitate in the absence of ligand $[1,6]$, implying that there is some dissociation of IFN- $\gamma \mathrm{R} 2$ from IFN- $\gamma \mathrm{R} 1$, and (ii) complexes between IFN- $\gamma \mathrm{R} 1$, IFN- $\gamma \mathrm{R} 2$ and IFN- $\gamma$ are stable to immunoprecipitation $[1,4,6]$, suggesting that this complex is quite spontaneously and stably formed even in the presence of dynamic IFN- $\gamma$ R $1: I F N-\gamma R 2$ interactions. At higher IFN- $\gamma$ concentrations, nearly all of the IFN- $\gamma \mathrm{R} 2$ would be associated with IFN- $\gamma$ :IFN- $\gamma$ R 1 complexes, and increasing numbers of lower affinity IFN- $\gamma$ :IFN- $\gamma \mathrm{R} 1$ complexes will exist and apparently inhibit rapid Stat 1 activation. Thus we speculate that the presence of IFN- $\gamma$ :IFN- $\gamma \mathrm{R} 1$ complexes which do not have IFN- $\gamma \mathrm{R} 2$ associated inhibit rapid Stat1 activation by complexes composed of IFN- $\gamma$, IFN- $\gamma \mathrm{R} 1$ and IFN- $\gamma$ R2. In support of this speculation, radiation-inactivation experiments demonstrated that a tetramer of IFN- $\gamma$ (two IFN- $\gamma$ dimers) was the biological unit observed during cell signaling, while a dimer of IFN- $\gamma$ was the biological unit observed in solution and during cell surface binding $[90,91]$. An interaction between an active IFN- $\gamma$ receptor complex and an active type I IFN receptor complex is thought to dramatically enhance the antiviral activity of IFN- $\gamma$ in mouse cells [92], implying that interactions between active receptor complexes may occur with other cytokine receptors.

The overexpression of the Jak kinase-defective FL-IFN$\gamma \mathrm{R} 2 / \alpha \mathrm{R} 2 \mathrm{~b}$ in HeLa cells prevented rapid Stat1 activation 
but did not inhibit the residual activation of Stat 1 by IFN- $\gamma$ (Figure 4). This result implies that the dominant-negative IFN- $\gamma \mathrm{R} 2$ chain cannot displace the endogenous IFN- $\gamma \mathrm{R} 2$ from endogenous IFN- $\gamma \mathrm{R} 1$. Because IFN- $\gamma \mathrm{R} 2$ is constitutively preassociated to IFN- $\gamma \mathrm{R} 1$ [3], some element in the intracellular domain of IFN- $\gamma \mathrm{R} 2$ is allowing IFN- $\gamma \mathrm{R} 1$ to remain stably associated with IFN- $\gamma \mathrm{R} 2$. This element cannot be the Jak2 association site or Jak2 because (1) Tyk 2 could functionally substitute for Jak2 without altering the activation of Stat 1 in HeLa cells (Figure 1D) or in hamster 16-9 cells [61], and (2) destruction of the Jak2 association site did not alter the constitutive interactions between IFN- $\gamma$ R1 and IFN- $\gamma$ R2 [93]. There are sections of the IFN- $\gamma \mathrm{R} 2$ intracellular domain that are conserved in evolution but are not involved in interactions with Jak2, such as Leu ${ }^{303}$ GluAlaLeuAspLysAsp ${ }^{309}$ and Asp ${ }^{314}$ AspValTrpAspSerValSerIleIle ${ }^{323}$; these regions may be required in

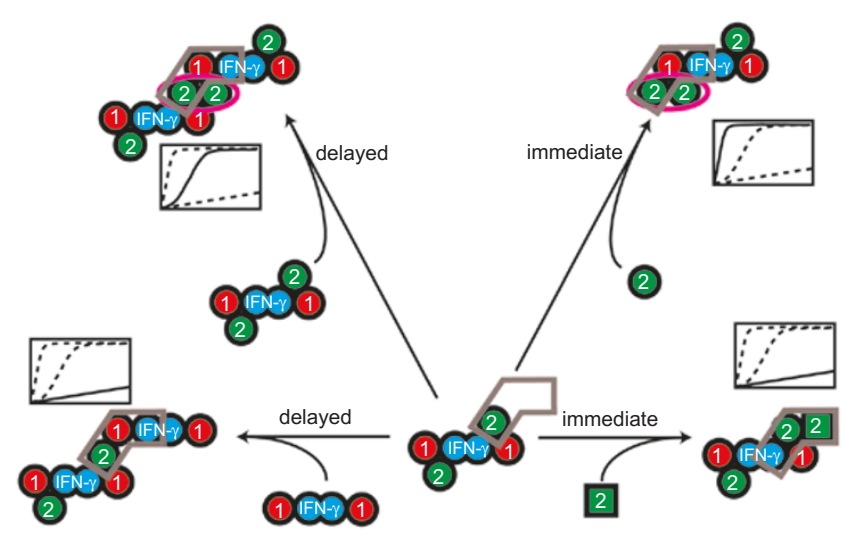

Figure 5 Model of interactions of signaling IFN- $\gamma$ receptor complexes with other receptors to modify Stat1 signaling. Views of the receptor complex are from above the cell, looking down on the receptor complex. IFN- $\gamma \mathrm{R} 2$ is represented by the green circle, IFN$\gamma \mathrm{R} 1$ by the red circle, IFN- $\gamma$ by the two fused light blue circles, and dominant-negative IFN- $\gamma \mathrm{R} 2 / \alpha \mathrm{R} 2 \mathrm{~b}$ with the green square. In each case, a common interaction (delineated with the grey bent box) can be seen in each scenario, depending on which is overexpressed. The juxtaposition of two IFN- $\gamma$ R2 chains, each binding Jak2 (the purple ellipse) correlates with the appearance of rapid Stat1 activation. The IFN- $\gamma$ receptor complex formed initially is shown in the bottom center. (upper right), when IFN- $\gamma \mathrm{R} 2$ is in excess, a rapid interaction with IFN- $\gamma$ R 2 results in rapid Stat 1 activation. The putative resulting complex is shown. (upper left), when neither chain is in excess, a delayed interaction with another receptor complex results in a delay prior to the onset of rapid Stat1 activation. (lower left) in the presence of excess IFN- $\gamma \mathrm{R} 1$, and high levels of IFN- $\gamma$, interactions with complexes of IFN- $\gamma$ and IFN- $\gamma$ R 1 prevent the juxtaposition of two IFN- $\gamma$ R2 chains, and no rapid Stat1 activation is seen. (lower right) overexpression of a IFN- $\gamma \mathrm{R} 2$ chain that lacks Jak2 results in the formation of complexes in which two Jak2 molecules cannot be juxtaposed, therefore no rapid Stat1 activation is seen. the interaction with IFN- $\gamma \mathrm{R} 1$ and therefore the constitutive interaction between IFN- $\gamma \mathrm{R} 1$ and IFN- $\gamma \mathrm{R} 2$. On the other hand, dominant-negative IFN- $\gamma \mathrm{R} 2$ effectively inhibited the rapid Stat 1 activation seen in regular HeLa cells. Thus we speculate that a secondary recruitment of additional Jak kinase activity (occurring physiologically by association with IFN- $\gamma \mathrm{R} 2$ ) mediated by the extracellular domain of IFN- $\gamma$ R 2 to an active IFN- $\gamma$ receptor complex accelerates Stat 1 activation.

We propose the following model (Figure 5) in an attempt to explain how changing the ratio of receptor chains changes the time course of Stat1 activation. Above we speculated that the extracellular domain of IFN- $\gamma \mathrm{R} 2$ was involved in recruiting the additional Jak2 kinase activity to a signaling IFN- $\gamma$ receptor complex. We also proposed that high amounts of IFN- $\gamma:$ IFN- $\gamma$ R 1 complexes inhibit rapid Stat1 activation, presumably by preventing the recruitment of additional IFN- $\gamma \mathrm{R} 2$ and its associated Jak2 activity. Thus somehow IFN- $\gamma$ :IFN- $\gamma$ R1 complexes also associate with a signaling IFN- $\gamma$ receptor complex to form an overall complex with two ligands bound to one active receptor complex and one inactive receptor complex. If IFN- $\gamma \mathrm{R} 2$ were associated with this IFN- $\gamma$ :IFN- $\gamma \mathrm{R} 1$ complex, then the interaction of two signaling complexes would recruit IFN- $\gamma \mathrm{R} 2$ to a signaling complex, and rapid Stat 1 activation would result. This likely represents the situation in which neither IFN- $\gamma$ R2 nor IFN- $\gamma$ R 1 is overexpressed, and only a short slow phase exists; perhaps some time is needed to generate enough signaling complexes to see significant dimerization of the complexes. Combining all these considerations, we hypothesize that an association between the extracellular domains of ligand-bound IFN- $\gamma \mathrm{R} 1$ from one complex and IFN- $\gamma$ R2 from another complex occurs; only when this interaction juxtaposes two Jak2 kinases will rapid Stat activation be observed.

\section{Acknowledgements}

We thank Michael Newlon for many comments and suggestions to improve the text. This study was supported in part by United States Public Health Services Grants RO1CA46465 from the National Cancer Institute, RO1 AI36450, RO1-AI43369, R01-AI059465 and 2T32AI07403 from the National Institute of Allergy and Infectious Diseases and from the National Institute of Allergy and Infectious Diseases, and an award from the Milstein Family Foundation to S Pestka.

\section{References}

1 Marsters SA, Pennica D, Bach E, et al. Interferon $\gamma$ signals via a high-affinity multisubunit receptor complex that contains two types of polypeptide chain. Proc Natl Acad Sci USA 1995; 
92:5401-5.

2 Pestka S, Kotenko SV, Muthukumaran G, et al. The interferon $\gamma$ (IFN- $\gamma$ ) receptor: a paradigm for the multichain cytokine receptor. Cytokine Growth Factor Rev 1997; 8:189-206.

3 Krause CD, Mei E, Xie J, et al. Seeing the light: preassembly and ligand-induced changes of the interferon $\gamma$ receptor complex in cells. Mol Cell Proteomics 2002; 1:805-15.

4 Igarashi K, Garotta G, Ozmen L, et al. Interferon- $\gamma$ induces tyrosine phosphorylation of interferon- $\gamma$ receptor and regulated association of protein tyrosine kinases, Jak1 and Jak2, with its receptor. J Biol Chem 1994; 269:14333-6.

5 Sakatsume M, Igarashi K, Winestock KD, et al. The Jak kinases differentially associate with the $\alpha$ and $\beta$ (accessory factor) chains of the interferon $\gamma$ receptor to form a functional receptor capable of activating STAT transcription factors. J Biol Chem 1995; 270:17528-34.

6 Kotenko SV, Izotova LS, Pollack BP, et al. Interaction between the components of the interferon $\gamma$ receptor complex. J Biol Chem 1995; 270:20915-21.

7 Greenlund AC, Farrar MA, Viviano BL, et al. Ligand-induced IFN $\gamma$ receptor tyrosine phosphorylation couples the receptor to its signal transduction system (p91). EMBO J 1994; 13:1591600.

8 Qing Y, Costa-Pereira AP, Watling D, et al. Role of tyrosine 441 of interferon- $\gamma$ receptor subunit 1 in SOCS-1-mediated attenuation of STAT1 activation. J Biol Chem 2005; 280:1849-53.

9 Gil MP, Bohn E, O'Guin AK, et al. Biologic consequences of Stat1-independent IFN signaling. Proc Natl Acad Sci U S A 2001; 98:6680-5.

10 Ramana CV, Gil MP, Han Y, et al. Stat1-independent regulation of gene expression in response to IFN- $\gamma$. Proc Natl Acad Sci U S A 2001; 98:6674-9.

11 Song MM, Shuai K. The suppressor of cytokine signaling (SOCS) 1 and SOCS3 but not SOCS2 proteins inhibit interferon-mediated antiviral and antiproliferative activities. J Biol Chem 1998; 273:35056-62.

12 Haspel RL, Salditt-Georgieff M, Darnell JE Jr. The rapid inactivation of nuclear tyrosine phosphorylated Stat1 depends upon a protein tyrosine phosphatase. EMBO J 1996; 15:6262-8.

13 You M, Yu DH, Feng GS. Shp-2 tyrosine phosphatase functions as a negative regulator of the interferon-stimulated Jak/STAT pathway. Mol Cell Biol 1999; 19:2416-24.

14 Myers MP, Andersen JN, Cheng A, et al. TYK2 and JAK2 are substrates of protein tyrosine phosphatase 1B. J Biol Chem 2001; 276:47771-4.

15 Liu B, Liao J, Rao X, et al. Inhibition of Stat1-mediated gene activation by PIAS1. Proc Natl Acad Sci U S A 1998; 95:1062631.

16 Starr R, Hilton DJ. Negative regulation of the JAK/STAT pathway. Bioessays 1999; 21:47-52.

17 Sakamoto H, Kinjyo I, Yoshimura A. The janus kinase inhibitor, $\mathrm{Jab} / \mathrm{SOCS}-1$, is an interferon- $\gamma$ inducible gene and determines the sensitivity to interferons. Leuk Lymphoma 2000; 38:49-58.

18 Saito H, Morita Y, Fujimoto M, et al. IFN regulatory factor1-mediated transcriptional activation of mouse STAT-induced STAT inhibitor-1 gene promoter by IFN- $\gamma$. J Immunol 2000; 164:5833-43.

19 Endo TA, Masuhara M, Yokouchi M, et al. A new protein containing an SH2 domain that inhibits JAK kinases. Nature 1997;
387:921-4.

20 Pine R, Canova A, Schindler C. Tyrosine phosphorylated p91 binds to a single element in the ISGF2/IRF-1 promoter to mediate induction by IFN $\alpha$ and IFN $\gamma$, and is likely to autoregulate the p91 gene. EMBO J 1994; 13:158-67.

21 Hobart M, Ramassar V, Goes N, et al. The induction of class I and II major histocompatibility complex by allogeneic stimulation is dependent on the transcription factor interferon regulatory factor 1 (IRF-1): observations in IRF-1 knockout mice. Transplantation 1996; 62:1895-901.

22 Chow WA, Fang JJ, Yee JK. The IFN regulatory factor family participates in regulation of Fas ligand gene expression in T cells. J Immunol 2000; 164:3512-8.

23 Kim EJ, Lee JM, Namkoong SE, et al. Interferon regulatory factor- 1 mediates interferon- $\gamma$-induced apoptosis in ovarian carcinoma cells. J Cell Biochem 2002; 85:369-80.

24 Ruiz-Ruiz C, Ruiz de Almodovar C, Rodriguez A, et al. The upregulation of human caspase- 8 by interferon- $\gamma$ in breast tumor cells requires the induction and action of the transcription factor interferon regulatory factor-1. J Biol Chem 2004; 279:1971220.

25 Collart MA, Belin D, Vassalli JD, et al. $\gamma$ interferon enhances macrophage transcription of the tumor necrosis factor/cachectin, interleukin 1, and urokinase genes, which are controlled by shortlived repressors. J Exp Med 1986; 164:2113-8.

26 Tsujimoto M, Yip YK, Vilcek J. Interferon- $\gamma$ enhances expression of cellular receptors for tumor necrosis factor. J Immunol 1986; 136:2441-4.

27 Tsujimoto M, Vilcek J. Tumor necrosis factor receptors in HeLa cells and their regulation by interferon- $\gamma$. J Biol Chem 1986; 261:5384-8.

28 Tsujimoto M, Feinman R, Vilcek J. Differential effects of type I IFN and IFN- $\gamma$ on the binding of tumor necrosis factor to receptors in two human cell lines. J Immunol 1986; 137:2272-6.

29 Ruggiero V, Tavernier J, Fiers W, et al. Induction of the synthesis of tumor necrosis factor receptors by interferon- $\gamma$. J Immunol 1986; 136:2445-50.

30 Pandita R, Pocsik E, Aggarwal BB. Interferon- $\gamma$ induces cell surface expression for both types of tumor necrosis factor receptors. FEBS Lett 1992; 312:87-90.

31 Ossina NK, Cannas A, Powers VC, et al. Interferon- $\gamma$ modulates a p53-independent apoptotic pathway and apoptosis-related gene expression. J Biol Chem 1997; 272:16351-7.

32 Kumar A, Commane M, Flickinger TW, et al. Defective TNF$\alpha$-induced apoptosis in STAT1-null cells due to low constitutive levels of caspases. Science 1997; 278:1630-2.

$33 \mathrm{Xu}$ X, Fu XY, Plate J, et al. IFN- $\gamma$ induces cell growth inhibition by Fas-mediated apoptosis: requirement of STAT1 protein for up-regulation of Fas and FasL expression. Cancer Res 1998; 58:2832-7.

34 Shustov A, Nguyen P, Finkelman F, et al. Differential expression of Fas and Fas ligand in acute and chronic graft-versus-host disease: up-regulation of Fas and Fas ligand requires CD8+ T cell activation and IFN- $\gamma$ production. J Immunol 1998; 161:284855.

35 Sedger LM, Shows DM, Blanton RA, et al. IFN- $\gamma$ mediates a novel antiviral activity through dynamic modulation of TRAIL and TRAIL receptor expression. J Immunol 1999; 163:920-6.

36 Chin YE, Kitagawa M, Kuida K, et al. Activation of the STAT 
signaling pathway can cause expression of caspase 1 and apoptosis. Mol Cell Biol 1997; 17:5328-37.

37 Dai C, Krantz SB. Interferon $\gamma$ induces upregulation and activation of caspases 1,3 , and 8 to produce apoptosis in human erythroid progenitor cells. Blood 1999; 93:3309-16.

38 Fulda S, Debatin KM. IFN $\gamma$ sensitizes for apoptosis by upregulating caspase- 8 expression through the Stat 1 pathway. Oncogene 2002; 21:2295-308.

39 Chon SY, Hassanain HH, Gupta SL. Cooperative role of interferon regulatory factor 1 and p91 (STAT1) response elements in interferon- $\gamma$-inducible expression of human indoleamine 2,3dioxygenase gene. J Biol Chem 1996; 271:17247-52.

40 Boehm U, Klamp T, Groot M, et al. Cellular responses to interferon- $\gamma$. Annu Rev Immunol 1997; 15:749-95.

41 Barber GN. The interferons and cell death: guardians of the cell or accomplices of apoptosis? Semin Cancer Biol 2000; 10:103-11.

42 Schroder K, Hertzog PJ, Ravasi T, et al. Interferon- $\gamma$ : an overview of signals, mechanisms and functions. J Leukoc Biol 2004; 75:163-89.

43 Buschle M, Campana D, Carding SR, et al. Interferon $\gamma$ inhibits apoptotic cell death in B cell chronic lymphocytic leukemia. J Exp Med 1993; 177:213-8.

44 Yong VW, Moumdjian R, Yong FP, et al. $\gamma$-interferon promotes proliferation of adult human astrocytes in vitro and reactive gliosis in the adult mouse brain in vivo. Proc Natl Acad Sci U S A 1991; 88:7016-20.

45 Novelli F, Bernabei P, Ozmen L, et al. Switching on of the proliferation or apoptosis of activated human $\mathrm{T}$ lymphocytes by IFN- $\gamma$ is correlated with the differential expression of the $\alpha$ - and $\beta$-chains of its receptor. J Immunology 1996; 157:1935-43.

46 Novelli F, D'Elios MM, Bernabei P, et al. Expression and role in apoptosis of the $\alpha$-and $\beta$-chains of the IFN- $\gamma$ receptor on human Th1 and Th2 clones. J Immunol 1997; 159:206-13.

47 Drexler HG, Zaborski M, Quentmeier H. Interferon- $\gamma$ induced proliferation of human myeloid leukaemia cell lines. Br J Haematol 1997; 98:699-710.

48 Rubio N, Torres C. Interferon- $\gamma$ induces proliferation but not apoptosis in murine astrocytes through the differential expression of the myc proto-oncogene family. Brain Res Mol Brain Res 1999; 71:104-10.

49 Asao H, Fu XY. Interferon- $\gamma$ has dual potentials in inhibiting or promoting cell proliferation. J Biol Chem 2000; 275:867-74.

50 Bernabei P, Coccia EM, Rigamonti L, et al. Interferon- $\gamma$ receptor 2 expression as the deciding factor in human T, B, and myeloid cell proliferation or death. J Leukoc Biol 2001; 70:950-60.

51 Costa-Pereira AP, Tininini S, Strobl B, et al. Mutational switch of an IL-6 response to an interferon- $\gamma$-like response. Proc Natl Acad Sci U S A 2002; 99:8043-7.

52 Orchansky P, Rubinstein M, Fischer DG. The interferon- $\gamma$ receptor in human monocytes is different from the one in nonhematopoietic cells. J Immunol 1986; 136:169-73.

53 Fischer DG, Novick D, Orchansky P, et al. Two molecular forms of the human interferon- $\gamma$ receptor. Ligand binding, internalization, and down-regulation. J Biol Chem 1988; 263:2632-7.

54 Novelli F, Di Pierro F, Francia di Celle P, et al. Environmental signals influencing expression of the IFN- $\gamma$ receptor on human $\mathrm{T}$ cells control whether IFN- $\gamma$ promotes proliferation or apoptosis. J Immunology 1994; 152:496-504.

55 Pernis A, Gupta S, Gollob KJ, et al. Lack of interferon $\gamma$ receptor $\beta$ chain and the prevention of interferon $\gamma$ signaling in $\mathrm{T}_{\mathrm{H}} 1$ cells. Science 1995; 269:245-7.

56 Bach EA, Szabo SJ, Dighe AS, et al. Ligand-induced autoregulation of IFN- $\gamma$ receptor $\beta$ chain expression in Thelper cell subsets. Science $1995 ; 270: 1215-8$.

57 Skrenta H, Peritt D, Cook JR, et al. The expression of the second interferon $\gamma$ receptor chain (IFN- $\gamma$ R2) distinguishes human cytotoxic $(\mathrm{CD} 8+)$ as well as helper (CD4+) T-cell subsets. Eur Cytokine Net 1996; 7:622.

58 Sakatsume M, Finbloom DS. Modulation of the expression of the IFN- $\gamma$ receptor $\beta$-chain controls responsiveness to IFN- $\gamma$ in human peripheral blood T cells. J Immunol 1996; 156:4160-6.

59 Groux H, Sornasse T, Cottrez F, et al. Induction of human T helper cell type 1 differentiation results in loss of IFN- $\gamma$ receptor $\beta$-chain expression. J Immunol 1997; 158:5627-31.

60 Kung H, Pan YE, Moschera J, et al. Purification of recombinant human immune interferon. Meth In Enzym 1986; 119:204-10.

61 Kotenko SV, Izotova LS, Pollack BP, et al. Other kinases can substitute for Jak2 in signal transduction by interferon- $\gamma$. J Biol Chem 1996; 271:17174-82.

62 Kotenko SV, Krause CD, Izotova LS, et al. Identification and characterization of a second chain of the interleukin-10 receptor complex. EMBO J 1997; 16:5894-903.

63 Kotenko SV, Izotova LS, Mirochnitchenko OV, et al. The intracellular domain of interferon- $\alpha$ receptor $2 c$ (IFN- $\alpha \mathrm{R} 2 \mathrm{c}$ ) chain is responsible for Stat activation. Proc Natl Acad Sci U S A 1999; 96:5007-12.

64 Garotta G, Ozmen L, Fountoulakis M, et al. Human interferon- $\gamma$ receptor. Mapping of epitopes recognized by neutralizing antibodies using native and recombinant receptor proteins. J Biol Chem 1990; 265:6908-15.

65 Livnah O, Johnson DL, Stura EA, et al. An antagonist peptideEPO receptor complex suggests that receptor dimerization is not sufficient for activation. Nat Struct Bio 1998; 5:993-1004.

66 Krause CD, Lunn CA, Izotova LS, et al. Studies on signaling of covalent heterodimers of interferon- $\gamma$ : evidence for one-sided signaling in the active tetrameric receptor complex. J Biol Chem 2000; 275:22995-3004.

67 Dignam JD, Lebovitz RM, Roeder RG. Accurate transcription initiation by RNA polymerase II in a soluble extract isolated mammalian nuclei. Nuc Acids Res 1983; 11:1475-89.

68 Swillins S, Cochaux P, Lecocq R. A pitfall in the computer-aided quantification of autoradiograms. Trends in Bioch Sci 1989; 14:440-1.

69 Kile BT, Nicola NA, Alexander WS. Negative regulators of cytokine signaling. Int J Hematol 2001; 73:292-8.

70 Chen W, Daines MO, Khurana Hershey GK. Turning off signal transducer and activator of transcription (STAT): the negative regulation of STAT signaling. J Allergy Clin Immunol 2004; 114:476-89.

71 Bai L, Merchant JL. Transcription factor ZBP-89 is required for STAT1 constitutive expression. Nucleic Acids Res 2003; 31:7264-70.

72 Parisien JP, Lau JF, Rodriguez JJ, et al. Selective STAT protein degradation induced by paramyxoviruses requires both STAT1 and STAT2 but is independent of $\alpha / \beta$ interferon signal transduction. J Virol 2002; 76:4190-8.

73 Hendry L, John S. Regulation of STAT signalling by proteolytic processing. Eur J Biochem 2004; 271:4613-20. 
74 Rogers RS, Horvath CM, Matunis MJ. SUMO modification of STAT1 and its role in PIAS-mediated inhibition of gene activation. J Biol Chem 2003; 278:30091-7.

75 Ungureanu D, Vanhatupa S, Kotaja N, et al. PIAS proteins promote SUMO-1 conjugation to STAT1. Blood 2003; 102:33113.

76 Liu B, Mink S, Wong KA, et al. PIAS1 selectively inhibits interferon-inducible genes and is important in innate immunity. Nat Immunol 2004; 5:891-8.

77 Eilers A, Georgellis D, Klose B, et al. Differentiation-regulated serine phosphorylation of STAT1 promotes GAF activation in macrophages. Mol Cell Biol 1995; 15:3579-86.

78 Eilers A, Decker T. Activity of Stat family transcription factors is developmentally controlled in cells of the macrophage lineage. Immunobiology 1995; 193:328-33.

79 McDowell MA, Lucas DM, Nicolet CM, et al. Differential utilization of IFN- $\gamma$-responsive elements in two maturationally distinct macrophage cell lines. J Immunol 1995; 155:4933-8.

80 Lucas DM, Lokuta MA, McDowell MA, et al. Analysis of the IFN- $\gamma$-signaling pathway in macrophages at different stages of maturation. J Immunol 1998; 160:4337-42.

81 Köster M, Hauser H. Dynamic redistribution of STAT1 protein in IFN signaling visualized by GFP fusion proteins. Eur J Biochem 1999; 260:137-44.

82 Quirk SM, Cowan RG, Huber SH. Fas antigen-mediated apoptosis of ovarian surface epithelial cells. Endocrinology 1997; 138:4558-66.

83 Rhee S, Ebensperger C, Dembic Z, et al. The structure of the gene for the second chain of the human interferon- $\gamma$ receptor. $\mathrm{J}$ Biol Chem 1996; 271:28947-52.
84 Ebensperger C, Rhee S, Muthukumaran G, et al. Genomic organization and promoter analysis of the gene ifngr 2 encoding the second chain of the mouse interferon- $\gamma$ receptor. Scand J Immunol 1996; 44:599-606.

85 Skrenta H, Yang Y, Pestka S, et al. Ligand-independent downregulation of IFN- $\gamma$ receptor 1 following TCR engagement. J Immunol 2000; 164:3506-11.

86 Rigamonti L, Ariotti S, Losana G, et al. Surface expression of the IFN- $\gamma$ R2 chain is regulated by intracellular trafficking in human T lymphocytes. J Immunol 2000; 164:201-7.

87 Bernabei P, Bosticardo M, Losana G, et al. IGF-1 down-regulates IFN- $\gamma$ R2 chain surface expression and desensitizes IFN- $\gamma /$ STAT-1 signaling in human T lymphocytes. Blood 2003; 102:2933-9.

88 Lai D. The mapping of the murine and human interferon $\gamma$ receptor. 1994;

89 Faltynek CR, Princler GL. Modulation of interferon- $\alpha$ and interferon- $\gamma$ receptor expression during T-lymphocyte activation and proliferation. J Interferon Res 1986; 6:639-53.

90 Pestka S, Kelder B, Familletti PC, et al. Molecular weight of the functional unit of human leukocyte, fibroblast, and immune interferons. J Biol Chem 1983; 258: 9706-9.

91 Langer JA, Rashidbaigi A, Garotta G, et al. Radiation inactivation of human $\gamma$-interferon: cellular activation requires two dimers. Proc Natl Acad Sci USA 1994; 91:5818-22.

92 Takaoka A, Mitani Y, Suemori H, et al. Cross talk between interferon- $\gamma$ and $-\alpha / \beta$ signaling components in caveolar membrane domains. Science 2000; 288:2357-60.

93 Krause CD, Lavnikova N, Xie J, et al. Preassembly and ligandinduced restructuring of the chains of the IFN- $\gamma$ receptor complex: the roles of Jak kinases, Stat 1 and the receptor chains. Cell Research 2006; 16:55-69. 